\title{
A Importância da Caracterização dos Visitantes nas Ações de Ecoturismo e Educação Ambiental do Parque Nacional da Serra do Cipó/MG.
}

\author{
The Importance of Visitors Characterization to Ecotourism and Environmental Education \\ Actions in Serra do Cipó National Park.
}

\section{La Importancia de la Caracterización de los Visitantes en las Acciones de Ecoturismo e de Educación Ambiental en el Parque Nacional da Serra do Cipó/MG.}

\author{
Renata Ferreira Campos ${ }^{1}$ \\ Fernanda Carla Wasner Vasconcelos ${ }^{2}$ \\ Lilian Araújo Grossi Félix ${ }^{3}$
}

\section{Resumo}

O objetivo deste trabalho foi conhecer o perfil dos visitantes do Parque Nacional da Serra do Cipó de forma a contribuir para o planejamento do ecoturismo e de ações de educação ambiental neste destino. O Parque Nacional da Serra do Cipó se situa no distrito de mesmo nome, pertencente ao município de Santana do Riacho, distante cerca de $100 \mathrm{~km}$ de Belo Horizonte/MG. Foram analisados 53 questionários, aplicados nos dias 18 e 19 de setembro de 2010. Verificou-se que o perfil dos visitantes encaixa-se dentro do comumente proposto na literatura para ecoturistas. Predominam visitantes jovens, com renda elevada, alto nível de escolaridade, provenientes de Belo Horizonte e de sua Região Metropolitana. A maioria dos entrevistados reconhece os objetivos principais de um Parque, bem como a importância de um centro de visitantes e demonstra disposição a seguir regras de conservação da natureza e a participar de atividades de educação ambiental. Apesar de não possuírem um conceito formulado de ecoturismo, mais da metade dos visitantes se considera ecoturista. Recomendase assim, a utilização dos princípios do ecoturismo e, conseqüentemente, da educação ambiental, nas ações desenvolvidas pelo Parque Nacional da Serra do Cipó, em seu uso público. Dessa forma, acredita-se que o turismo possa ser verdadeiramente econômico, social, cultural e ecologicamente sustentável, além de fonte de conservação ambiental.

Palavras-chave: unidades de conservação; sustentabilidade; lazer.

\section{Abstract}

The aim of this work is to know the visitors of the Serra do Cipó National Park, contributing to the management of ecotourism and actions towards environmental education. The Serra do Cipó National Park is located in a district with the same name that belongs to the Santana do Riacho city, around $100 \mathrm{~km}$ away from Belo Horizonte/MG. 53 questionnaires, applied at

\footnotetext{
${ }^{1}$ Bióloga. Especialista em Ecoturismo. Mestranda em Turismo e Meio Ambiente pelo Centro Universitário UNA. Faculdade Presidente Antônio Carlos de Sabará. E-mail: renata001@gmail.com.

${ }^{2}$ Doutora em Ciências. Professora do Mestrado de Turismo e Meio Ambiente, Centro Universitário UNA / UNATEC. E-mail: fernanda.wasner@prof.una.br.

3 Pedagoga. Especialista em Educação a Distância. Mestranda em Turismo e Meio Ambiente. Faculdade Presidente Antônio Carlos de Sabará. E-mail: liligrossi@hotmail.com.
} 
September 18 and 19 of 2010, where analyzed. It was found that young predominate, with high educational standards and high income, coming from Belo Horizonte and its metropolitan area. Most of them recognize a park's main purposes as well as the importance of visitor's center; they also agree and are willing to follow the rules of nature conservation as well as to participate of the environmental education activities. Despite the lack of a correct concept of ecotourism more than half of the visitors consider themselves as ecotourists. It's advisable the use of ecotourism principles and consequently of environmental education to the actions developed by the Serra do Cipó National Park in its public use. Those observations lead to believe that tourism can be truly economic, social, cultural and ecologically sustainable, and also a source of environmental conservancy.

Keywords: conservation units; sustainability; leisure.

\section{Resumen}

El objectivo de este trabajo fue conocer el perfil de los visitantes del Parque Nacional de la Sierra del Cipó de forma que contribuya para la planificación del ecoturismo y de acciones de educación ambiental en el destino. El Parque Nacional de la Sierra del Cipó esta localizado en el distrito del mismo nombre, que pertence a la ciudad de Santana do Riacho, distante de Belo Horizonte alrededor de $100 \mathrm{~km}$. Se analizaron 53 cuestionarios, aplicados en los dias 18 y 19 de septiembre de 2010. Se verificó que el perfil de los visitantes se ajusta a lo que es comunmente propuesto en la literatura para ecoturistas. Predominan los visitantes jóvenes, com renta elevada, alto nivel de escolaridad, que vienen de Belo Horizonte y región metropolitana. La mayoría de los entrevistados reconoce los objetivos principales de un parque, así como la importancia de un centro de visitantes y demuestra disposición de seguir lãs normas de conservación de la naturaleza y participar de las actividades de educación ambiental. A pesar de no tener un concepto correctamente formulado de ecoturismo, más de la mitad de los visitantes se considera ecoturista. Recomiendase así, la utilización de los principios del ecoturismo, y por consiguiente, de la educación ambiental, en lãs acciones desarolladas por el Parque Nacional de la Sierra del Cipó, en su uso publico. De esa forma, se cree que el turismo puede ser verdaderamente económico, social, cultural y ecologicamente sostenible, además de ser una fuente de conservacion ambiental.

Palabras clave: unidades de conservación; sostenibilidad; ocio.

\section{Introdução}

Com o crescente interesse do homem pela natureza devido a uma maior conscientização para as questões ambientais, a uma busca nostálgica de vivência no meio natural e à conseqüente mudança dos valores culturais, uma das atividades mais procuradas no ramo do lazer tem sido o ecoturismo (CAMPOS, 2010). O aparecimento do ecoturismo e o seu acelerado crescimento têm suas raízes na insatisfação gerada pelo turismo convencional, ou turismo de massa. 
Pires (2002) acredita serem a curiosidade e o sentimento de nostalgia em relação a regiões remotas, as principais motivações de viagem dos seres humanos, quando se trata de turismo de natureza, ou mais especificamente, ecoturismo.

O ecoturismo surge, então, como um segmento do turismo, uma a modalidade cujas bases estão fincadas nas propostas do desenvolvimento sustentável: comprometimento com as gerações futuras, justiça social e eficiência econômica; considerando o ambiente nas suas múltiplas conexões - natural, econômica, social e cultural (FARIA; CARNEIRO, 2001).

Em 1994, com a publicação das diretrizes para uma Política Nacional de Ecoturismo, o ecoturismo foi conceituado como

um segmento da atividade turística que utiliza, de forma sustentável, o patrimônio natural e cultural, incentiva sua conservação e busca a formação de uma consciência ambientalista por meio da interpretação do ambiente, promovendo o bem-estar das populações (BRASIL, 1994).

Portanto, o ecoturismo não deve ser visto apenas como um turismo tradicional realizado em áreas naturais. $\mathrm{O}$ ecoturismo é uma atividade que depende da conservação do ambiente onde é praticado, e deve estar ligado à prática da educação ambiental (EA), da interpretação ambiental (IA) e das técnicas conservacionistas como uma forma de minimização dos impactos gerados. Deverá, também, atender às necessidades básicas da população local, assegurar a manutenção da diversidade cultural e das tradições da comunidade, além de garantir a participação da mesma nas tomadas de decisão (BENI, 2007).

Portanto, tanto a educação ambiental, como a interpretação ambiental são ferramentas úteis para sensibilização aos problemas ambientais e para capacitação da população na busca da sustentabilidade. Ambas almejam uma mudança de postura do ser humano frente à natureza. A diferença entre elas reside no fato de que a educação ambiental constitui um processo mais longo e contínuo, que deve acontecer ao longo de todas as fases da formação do indivíduo, enquanto que a interpretação ambiental é projetada para um momento específico e de curta duração. 
Além disso, a educação ambiental deve ser trabalhada em ambientes diversos, dentro e fora da sala de aula. Por outro lado, a interpretação ambiental geralmente é praticada em ambientes mais informais, como os ambientes naturais (PROJETO DOCES MATAS, 2002).

Segundo Vasconcelos (2003), a interpretação ambiental pode ser entendida como uma tradução da linguagem da natureza para linguagem comum dos visitantes, possibilitando informação em vez da distração e educação além do divertimento. Neste sentido, a interpretação é reconhecida como mais um recurso para o desenvolvimento dos programas de educação ambiental nas áreas protegidas, onde o propósito principal é aproximar os visitantes das questões ambientais.

Assim, a visita a áreas naturais protegidas é uma ótima oportunidade de se influenciar o processo de aprendizado dos turistas que procuram as unidades de conservação (UC). Uma vez que essas áreas oferecem experiências únicas para a (re)aproximação das pessoas aos ambientes naturais, aliando conhecimento, reflexões, desafios, afetividade, curiosidade, imaginação e noção de pertencimento. Fatores estes, que facilitam o cumprimento dos objetivos da educação ambiental e da conservação da natureza (VASCONCELLOS, 2006).

Portanto, a prática da educação e a interpretação ambiental são o grande diferencial do ecoturismo para outras formas de turismo. Sem um efetivo trabalho ambos, o ecoturismo apenas reafirma as práticas do turismo convencional, uma vez que os visitantes simplesmente passam pelos lugares e pessoas, meramente como lazer, fuga, válvula de escape à vida da cidade (HINTZE, 2009).

É imprescindível, então, que os turistas desenvolvam comportamentos sociais mais responsáveis e atitudes preservacionistas durante as suas viagens (RUSCHMANN, 2002). Faz-se necessário estimular a atenção, o olhar, o sentimento, a emoção, as sensações e as percepções do visitante para que ele possa experimentar o que, muitas vezes, é ignorado (BENI, 2007).

Barros e Dines (2000) acreditam que seja necessário que ocorra uma mudança de atitude, a qual só ocorrerá a partir da criação de vínculos entre ser humano e natureza, uma vez que a conscientização do indivíduo em relação ao ambiente é influenciada pela sua formação, pelo ambiente em que se situa e pela importância que reserva ao meio natural. Para tanto, os 
autores apostam nas técnicas de conduta consciente e de minimização de impactos na natureza.

Logo, uma percepção adequada do lugar é capaz de criar vínculos, e até um senso de responsabilidade com a possibilidade de transformar cada visitante em mais um aliado na conservação da natureza. Neste sentido, Niefer (2002) acredita ser indispensável que os administradores de UC's tenham conhecimento das características dos seus visitantes, tanto para elaborar estratégias de manejo dos visitantes como para tornar satisfatória a experiência turística.

Portanto, para o planejamento e manejo do ecoturismo em áreas protegidas, é preciso, além de conhecer o perfil do turista que visita a área, investigar sua percepção, motivações, expectativas, atitudes, valores e condutas. Conseqüentemente, a caracterização dos turistas que visitam o Parque Nacional da Serra do Cipó, assim como a relação que estabelecem com o local, é uma forma importante de orientação para as ações de planejamento e manejo do turismo na região. Uma vez que tais atividades, se bem conduzidas, podem ser sinônimo de preservação, conservação e revitalização de ambientes naturais e culturais (CAMPOS, 2010).

Assim, o presente trabalho tem como objetivo geral reunir informações capazes de contribuir com o planejamento futuro do Parque, para atividades e potenciais ações de manejo, de forma a conciliar as necessidades educacionais e recreativas com a conservação dos recursos naturais. O que será feito a partir do conhecimento do perfil, das atitudes e da consciência ambiental dos visitantes do Parque Nacional da Serra do Cipó.

\section{Métodos}

Este estudo foi desenvolvido na Serra do Cipó, que está situada na parte central do Estado de Minas Gerais, no sul da Cadeia do Espinhaço. O distrito da Serra do Cipó, anteriormente denominado Cardeal Mota, pertence ao município de Santana do Riacho e está localizado a cerca de $100 \mathrm{~km}$ ao norte de Belo Horizonte (SATO, 2007).

A região possui duas Unidades de Conservação: o Parque Nacional (PARNA) da Serra do Cipó, que apresenta uma área total de 31.733 hectares e $120 \mathrm{~km}$ de perímetro, estendendo-se pelos municípios de Jaboticatubas, Santana do Riacho, Morro do Pilar e Itambé do Mato 
Dentro. Já, em seu entorno, a Área de Proteção Ambiental (APA) Morro da Pedreira, que conta com uma área total de 66.200 hectares e compreende os municípios de Santana do Riacho, Conceição do Mato Dentro, Itambé do Mato Dentro, Morro do Pilar, Jaboticatubas, Taguaraçu de Minas, Itabira e Nova União (IBAMA, 2004).

As localizações do PARNA Serra do Cipó e da APA Morro da Pedreira são mostradas na Figura 1.
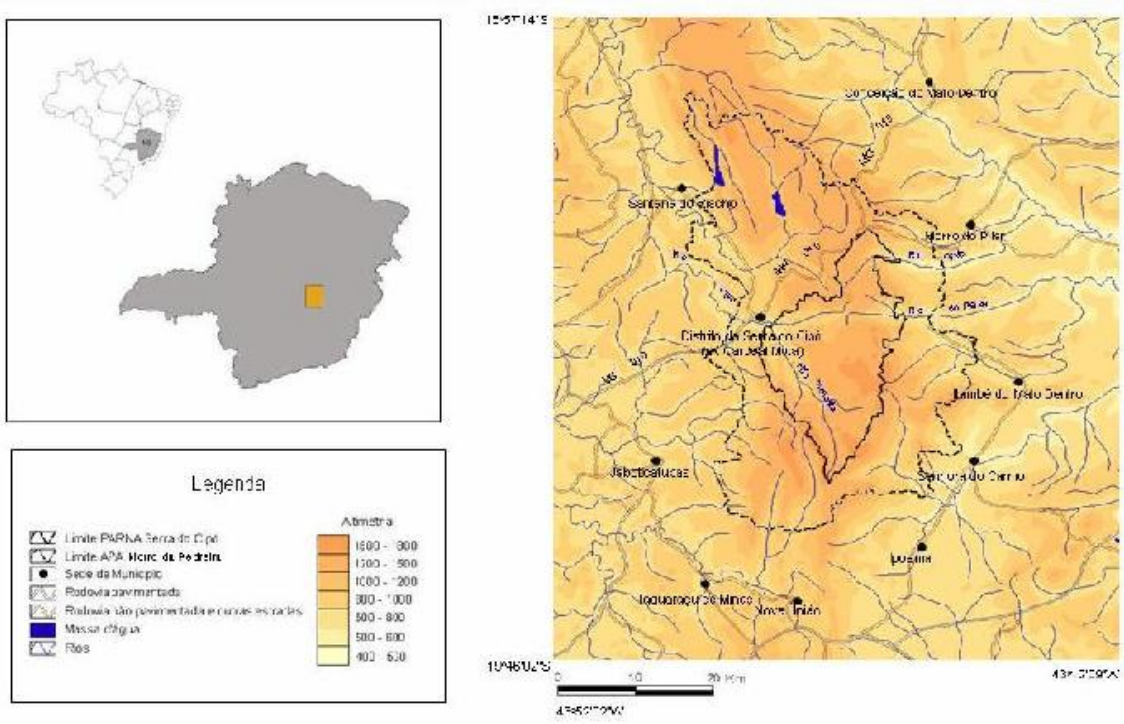

Fonte: SATO, 2007.

Figura 1 - Localização do Parque Nacional da Serra do Cipó e da APA Morro da Pedreira.

Foi elaborado um questionário contendo 21 questões adaptadas dos estudos de Niefer (2002), Simiquelli (2008) e Campos (2010).

O tipo de amostra utilizada foi a "não probabilística por conveniência" (ou acidental), onde o elemento pesquisado é selecionado por estar disponível no local e no momento em que a pesquisa estava sendo realizada (MATTAR, 1997). Foram aplicados um total 53 questionários, nos dias 18 e 19 de setembro de 2010. Os questionários foram respondidos pelos próprios visitantes, na Portaria do Parque Nacional da Serra do Cipó, após retornarem do passeio. Os dados foram devidamente tabulados e posteriormente analisados 
percentualmente para efetiva comparação das questões com base na sustentabilidade da atividade turística.

\section{Resultados}

A maior parte dos visitantes ( $86 \%$ ) é originária de Belo Horizonte e Região Metropolitana. O fácil acesso à região e a curta distância, cerca de $100 \mathrm{~km}$, entre Belo Horizonte e a Serra do Cipó, favorece a busca por esse destino, principalmente, nos finais de semana. Os outros visitantes são do interior de Minas Gerais (10\%) e, somente, 4\% de outros Estados.

Com relação ao gênero, não há diferença significativa, visto que foram entrevistados $51 \%$ de mulheres e $49 \%$ de homens.

No quesito idade, foram homogêneas, as faixas etárias entre 19 e 24 anos e entre 35 e 45 anos, que representam $25 \%$ e $23 \%$ do total de visitantes, respectivamente. No entanto, a maior parte dos visitantes (31\%) tem entre 25 e 34 anos. O que caracteriza um perfil de turistas jovens e adultos, que se enquadra no perfil de ecoturistas estudados por Ruschmann (2002).

O nível de escolaridade observado foi considerado elevado, uma vez que a grande maioria (83\%) possui ensino superior ou o está cursando. Sendo que destes, 23\% possuem algum curso de pós-graduação (Figura 2).

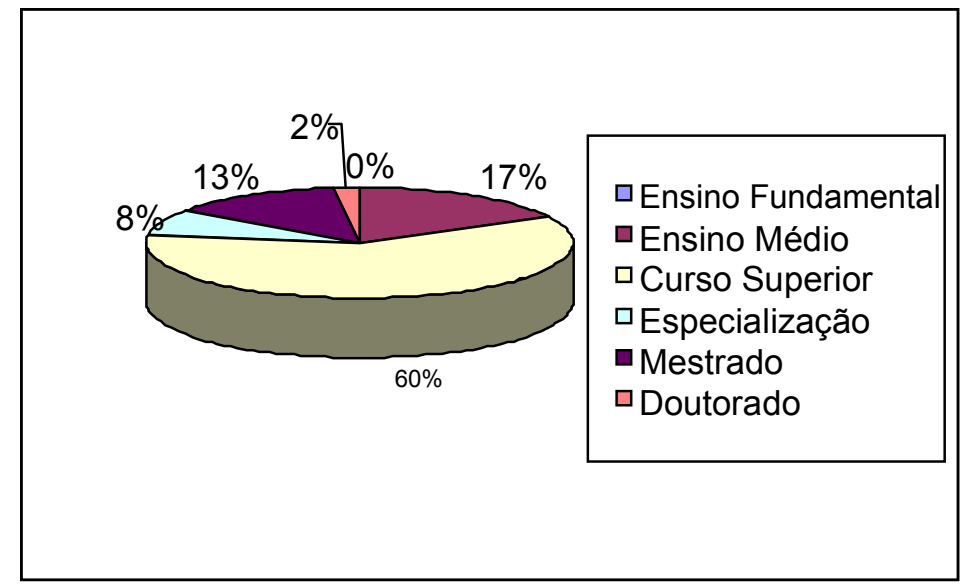

Figura 2 - Escolaridade dos visitantes do PARNA Serra do Cipó 
Este alto nível de escolaridade observado corresponde ao perfil do ecoturista em parques brasileiros como demonstram outros estudos. Ladeira et al. (2007) encontraram no Parque Estadual do Ibitipoca, uma predominância de pessoas com nível superior, $76 \%$ estão cursando ou possuem o ensino superior completo. No Parque Estadual do Jalapão, Dutra et al. (2008) também observaram um alto índice de entrevistados com nível superior, $64 \%$, sendo que $51 \%$ destes, possuíam pós-graduação.

De acordo com os estudos de Barros e Dines (2000), os ecoturistas apresentam um bom nível de escolaridade e são, normalmente, mais receptivos e conscientes das necessidades de conservação ambiental e das atratividades ecoturísticas. Portanto, se orientados, podem apresentar alto grau de comprometimento para a conservação destes locais, favorecendo, ainda, a implantação de projetos de educação ambiental.

Em relação à renda individual, o resultado foi bastante equilibrado (Figura 3). A maioria dos entrevistados (30\%) afirmou ganhar entre $\mathrm{R} \$ 2.000,00$ e $\mathrm{R} \$ 4.000,00$ mensais, e ainda 35\% disseram possuir uma renda individual superior a $\mathrm{R} \$ 4.000 .00$.

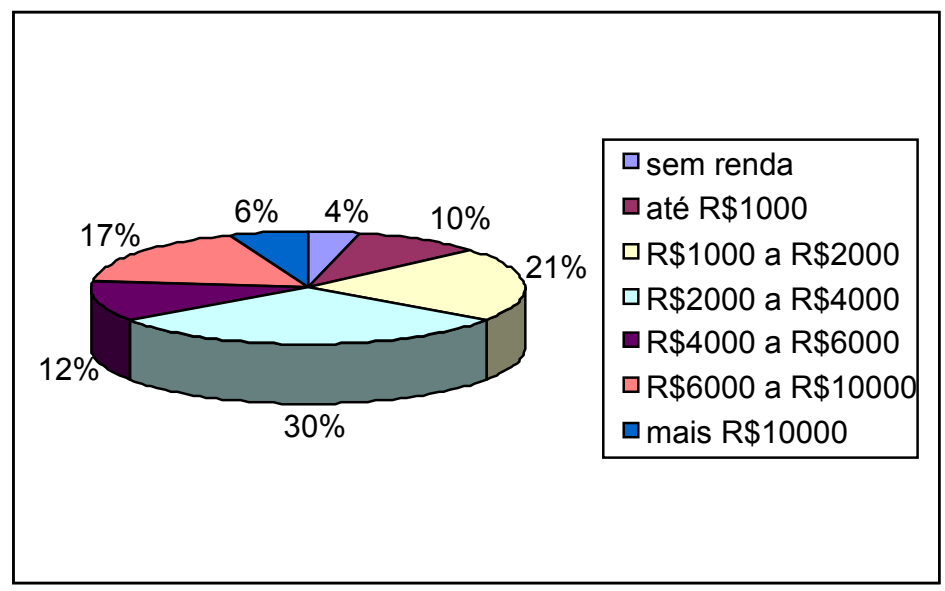

Figura 3 - Renda individual mensal do visitante

Também nas Ilhas do Mel e Superagui, cerca 29\% e 21\% dos entrevistados recebem mais de $\mathrm{R} \$ 4.000,00$ mensais, respectivamente, demonstrando um maior poder aquisitivo dos visitantes de áreas naturais em relação à maioria da população (NIEFER, 2002). Fato comprovado por Ruschmann (2002) que cita que os ecoturistas brasileiros possuem renda média superior a $\mathrm{R} \$ 3.000,00$ mensais. 
A chamada propaganda "boca a boca" foi o principal meio pela qual os entrevistados tomaram conhecimento sobre a Serra do Cipó. $80 \%$ dos visitantes ouviram falar sobre o destino através de amigos e parentes (Figura 4). Fato que é observado também em outros roteiros de ecoturismo, como o Parque Estadual do Ibitipoca (LADEIRA et al., 2007), o Parque Estadual da Ilha Anchieta (KATAOKA, 2004) e as Ilhas do Mel e do Superagüi (NIEFER, 2002). E ainda por Sato (2007) e Campos (2010) no próprio Parque Nacional da Serra do Cipó.

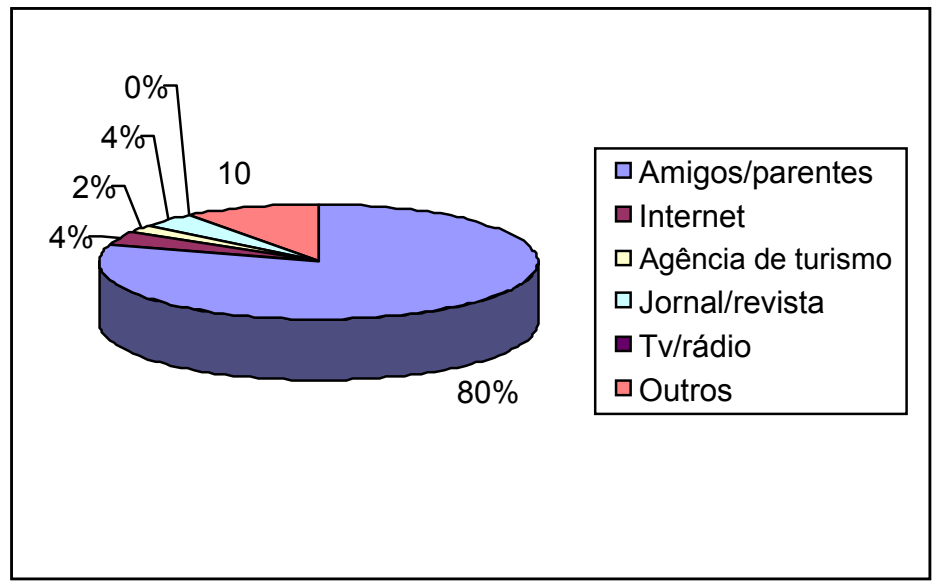

Figura 4 - Forma de tomar conhecimento do destino.

Kataoka (2004) acredita que a propaganda informal aumenta a importância de se entender as expectativas que os visitantes têm sobre a área visitada, pois, geralmente, os visitantes, que gostam da experiência e saem satisfeitos, acabam recomendando o local para outras pessoas e também levam amigos e parentes para o conhecerem, ou voltam para relembrar e ter uma nova experiência.

Em relação ao número de visitas que os entrevistados já fizeram à Serra do Cipó, a maioria (40\%) estava realizando sua primeira visita. No entanto, uma parcela também significativa dos entrevistados (34\%) costuma visitar o destino mais de três vezes ao ano. E os $26 \%$ restantes, vão de 1 a 3 vezes por ano à Serra do Cipó.

A freqüência com que as pessoas voltam a um mesmo destino pode se transformar em um ótimo fator de conservação do ambiente. Quando as pessoas assumem um ambiente como seu, quando sentem que fazem parte daquele ambiente, dificilmente vão querer agredi-lo, porque 
sabem que estarão agredindo a si mesmas. Ladeira et al. (2007) acreditam também que a assiduidade do turista com o destino estabelece uma relação mais comprometida com os problemas socioambientais da região, e pode servir como instrumento de pressão junto ao poder público para solução de problemas identificados na localidade.

Logo, o conhecimento das motivações que levam uma pessoa a visitar uma área natural é importante para que seja avaliado se as expectativas destes visitantes estão de acordo com o que o Parque pode oferecer (KATAOKA, 2004).

Foi então indagado aos visitantes, qual o seu interesse em algumas das possíveis atividades disponíveis na Serra do Cipó. O item de maior interesse foi o banho em rios e/ou cachoeiras, seguido de caminhadas longas (mais de duas horas de duração), observação da paisagem, bem como fotografá-la (Figura 5).

Em contrapartida, as atividades que despertam um menor interesse nos visitantes são: a vida noturna, a participação em pesquisas científicas e as atividades com a população local. Este resultado contradiz a "nova ética" idealizada para o turismo, em especial o ecoturismo, que segundo Pires (2002) é fundamentada em princípios como o respeito às populações locais e a valorização de sua cultura.

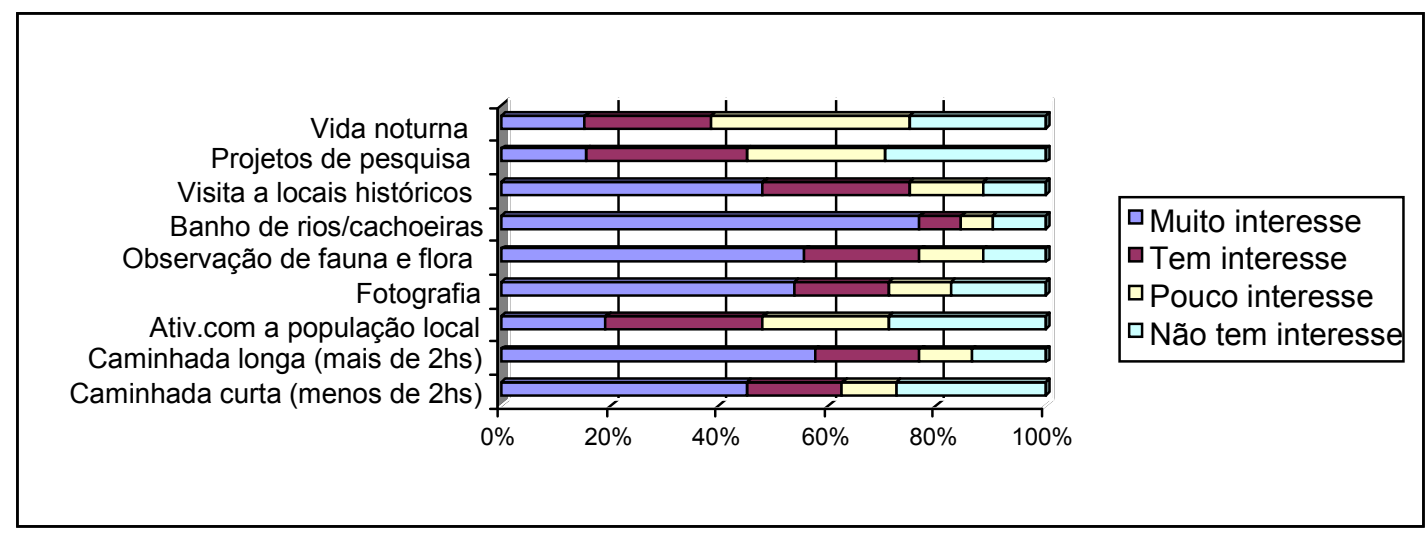

Figura 5 - Atividades de interesse dos visitantes

Quando questionados se tinham o costume de visitar outros Parques Nacionais (Estaduais/Municipais), 66\% dos entrevistados afirmaram que sim, enquanto 34\% não têm esse costume. 
Partindo da premissa que boa parte das pessoas, quando passam a visitar uma unidade de conservação com certa freqüência, tem uma predisposição a ter atitudes ecologicamente corretas, os Parques têm nesta realidade uma boa chance de aliar esta disposição natural com informações relevantes sobre conduta consciente em ambientes naturais (MELO et al., 2008). Os estudos de Kinker (2002) indicam ainda que quanto mais alta a freqüência de viagens a áreas naturais para o lazer, maior o grau de conscientização ambiental do viajante. Procurouse assim, saber quantas viagens à natureza os entrevistados haviam realizado no último ano. Quase a metade (42\%) disse ter feito menos de três viagens. 24\% viajaram entre quatro e seis vezes às áreas naturais no último ano, $12 \%$ entre sete e dez vezes e $10 \%$ fizeram mais de 10 viagens. $\mathrm{E}$ ainda, $12 \%$ dos entrevistados não haviam realizado nenhuma viagem no último ano.

Kinker (2002) assegura que a maneira como uma pessoa desfruta o seu passeio na natureza, está relacionada com a freqüência com que faz estes passeios. De acordo com a autora, a insegurança inicial nesse ambiente, natural do indivíduo que mora em centros urbanos, vai sendo substituída pela sensação de bem-estar a cada visita e, gradativamente, a curiosidade e o interesse pela natureza visitada geram um empenho maior do visitante em se informar sobre eles.

Questionados se gostariam de obter mais informações sobre o Parque Nacional da Serra do Cipó, 98\% dos entrevistados demonstraram ter interesse e apenas 2\% não. Tal resultado pode demonstrar uma carência de informações disponíveis, o que indica que o Parque tem se dedicado pouco à orientação do visitante, inclusive no que se refere aos usos e restrições.

Por outro lado, Dutra et al. (2008) acreditam que o interesse dos visitantes por maiores informações pode resultar na criação de atrativos culturais, como por exemplo, museus, galerias, casa da cultura, entre outros. Esses atrativos possibilitam a divulgação da cultura e da natureza da região, além de representar um instrumento de conscientização e educação dos turistas, repercutindo, assim, na conservação dos atrativos locais.

Quanto às formas de se obter maiores informações sobre o local, a grande maioria dos entrevistados $(72 \%)$ disse preferir receber as informações através da internet (Figura 6). 
Atualmente, a internet é um grande veículo de divulgação de destinos e de obtenção de informações por parte dos turistas.

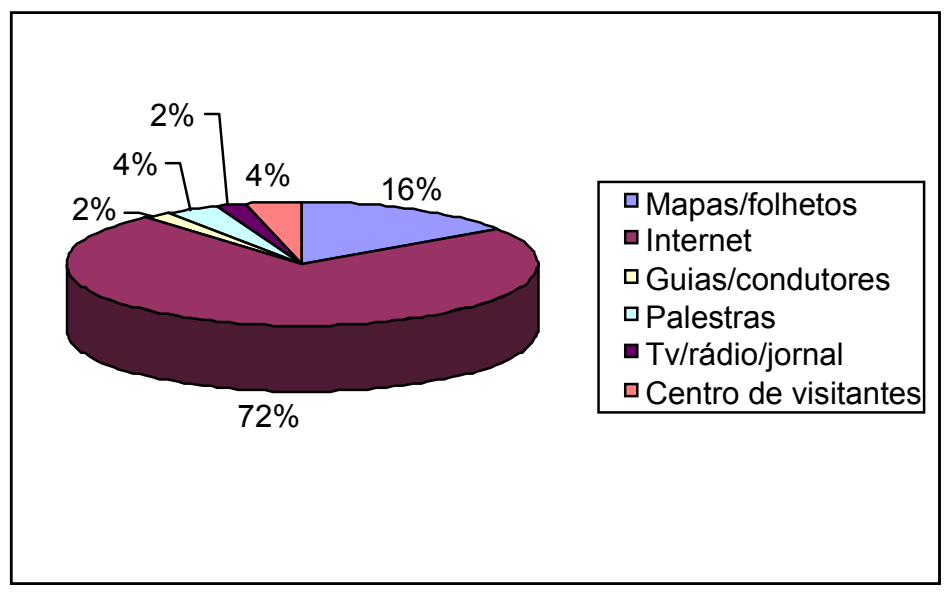

Figura 6 - Formas de obter informações do Parque.

De acordo com Marujo (2008), a internet tem a capacidade de fornecer informações com maior dinamismo, qualidade e economia. Além disso, facilita a pesquisa para a organização de uma viagem e multiplica as opções de destinos e possibilidades. Por isso, a autora acredita que a internet esteja se concretizando como um novo campo de batalha para os promotores dos destinos turísticos. "Atualmente, se um destino não figura na internet pode correr o risco de dar lugar a que o turista real ou potencial opte por outro destino" (MARUJO, 2008, p. 28).

Dessa forma, é importante que os gestores públicos estejam atentos a essa nova ferramenta para que possam utilizá-la adequadamente na divulgação do Parque, visando atender aos objetivos específicos do mesmo. Porém, é importante ressaltar que a internet possui um papel de divulgação, com informações concisas. Enquanto o centro de visitantes é um espaço de com papel de sensibilização do visitante, onde se dá a interpretação ambiental, de forma complementar às trilhas e demais atrativos do Parque.

Apesar de apenas 4\% dos visitantes terem escolhido o centro de visitantes como um instrumento para obtenção de maiores informações a respeito do Parque (Figura 6), a imensa maioria dos respondentes (94\%) considera que um centro de visitantes seja muito importante para o Parque. Sendo que os 6\% restantes, vêem pouca importância no mesmo. 
Segundo MMA (1998), um centro de visitantes é um espaço de apoio a uma variedade de programas e atividades que são desenvolvidos em uma unidade de conservação. E têm por objetivo propiciar a aproximação dos visitantes com a natureza, permitindo que estes interiorizem o significado das áreas protegidas, sua importância em termos de preservação, manejo e aproveitamento indireto dos recursos naturais e culturais.

Portanto, o principal compromisso com a implementação de um centro de visitantes é o de "despertar interesse no visitante e possibilitar que o seu contato com a natureza ou com os atributos culturais da Unidade torne-se uma experiência única e somente sua" (MMA, 1998, p.8).

O Parque Nacional da Serra do Cipó ainda não possui um centro de visitantes, mas o projeto para sua construção consta do plano de manejo da unidade, que está em fase de finalização.

Dessa maneira, perguntou-se aos visitantes, quais informações eles gostariam que o centro de visitantes do Parque possuísse. O resultado foi bastante equilibrado, como pode ser visto na figura 7. Informações gerais sobre a Serra do Cipó e sobre meio ambiente e biodiversidade foram as mais citadas, com $28 \%$ e $23 \%$ de preferência, respectivamente.

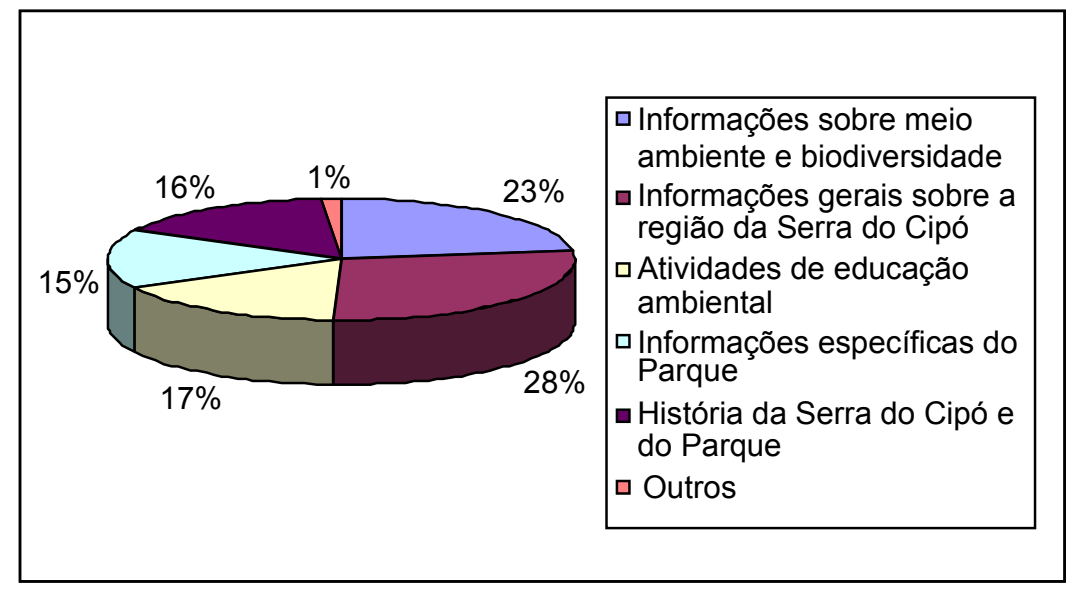

Figura 7 - Tópicos a serem abordados em um centro de visitantes

É importante ressaltar, também, o interesse dos visitantes em participar de atividades de educação ambiental, que aparece em terceiro lugar, com 17\% da preferência. 
A educação ambiental é uma das ferramentas fundamentais para a sensibilização e capacitação dos visitantes a respeito dos problemas socioambientais e de estratégias de conservação. Com ela, busca-se desenvolver técnicas e métodos que facilitem o processo de tomada de consciência sobre a gravidade dos problemas ambientais e a necessidade urgente de se debruçar seriamente sobre eles (MARCATTO, 2002).

Fortunato e Fortunato Neto (2010) lembram bem que a educação ambiental aqui referida não é aquela promovida pela mídia, que ensina a separar o lixo de acordo com a cor da lixeira. Nem as ações escolares que incentivam o plantio de árvores apenas na semana do meio ambiente. Os autores consideram que essas práticas, ainda que importantes, assemelha-se às práticas de adestramento e, na ausência do prêmio, o comportamento extingue-se.

Portanto, é necessário procurar formas alternativas de abordagem. Como por exemplo, o “Aprendizado Seqüencial”, método estruturado em fluxos de aprendizado, criado por Joseph Cornell e difundido pela Sharing Nature Foundation (BUENO, 2010).

O método traz em sua proposta metodológica a realização de dinâmicas e jogos, organizados e direcionados perante uma seqüência de quatro estágios (despertar do entusiasmo; concentrar a atenção; dirigir a experiência e compartilhar a inspiração) desenvolvidos com o intuito de criar um fluxo de energia, que vai de um estado de maior agitação para um estado de maior concentração da atenção e envolvimento (CORNELL, $1997^{4}$ apud BUENO, 2010).

Marcellino (2007) vê o lazer com um veículo privilegiado de educação e acredita que o aprendizado e o estímulo sejam necessários para que a prática positiva das atividades de lazer possibilite a passagem dos níveis mais simples, para níveis mais elaborados, nos quais haja o desenvolvimento do espírito crítico, seja na prática ou na observação. "Verifica-se, assim, um duplo processo educativo - o lazer como veículo e como objeto de educação" (MARCELLINO, 2007, p. 59).

Para Hintze (2009), a produção do conhecimento, na educação ambiental, acontece através da troca, da cooperação, e não por meio de relações professorais de imposição, pois "não se faz educação dentro da cabeça de ninguém, se faz educação no contexto histórico, no contexto

\footnotetext{
${ }^{4}$ CORNELL, J. A alegria de brincar com a natureza: atividades na natureza para todas as idades. São Paulo: Companhia Melhoramentos, Ed. SENAC 1997. 186 p.
} 
cultural. É por isso também que ela não pode ser neutra; não há, nunca houve, nem vai haver neutralidade educacional" (OVALLES; VIEZZER, 1995, p.14 apud HINTZE, 2009, p.72).

A solução, então, estaria na educação para uma vida sustentável. Dias (2003) acredita que a educação ambiental deve contemplar todos os aspectos do ambiente abrangendo as questões políticas, sociais, econômicas, científicas, tecnológicas, culturais, ecológicas e éticas. De acordo com UNESCO (2005), deve-se pensar e agir de forma diferente para que o processo de sustentabilidade tanto do homem, quanto do planeta, tenha início. Para que isto ocorra, a mudança deverá ser dar de maneira ascendente, ou seja, deve-se primeiramente transformar o indivíduo, em seguida, a comunidade; posteriormente, os sistemas e instituições sociais; e, por último, o meio ambiente.

É desta maneira, que segundo Moreira (2008), o indivíduo transforma-se no principal agente de mudança, sem o qual, os outros lugares sociais e o próprio meio ambiente não poderão ser alterados para a eficácia da sustentabilidade. Isso possibilita que a educação ambiental contribua, de maneira significativa, para a reavaliação de valores e de posturas que influenciam nos padrões de comportamento dos visitantes em ambientes naturais, sensibilizando-os e ensinando-os a viver parcimoniosamente com a natureza (FORTUNATO; FORTUNATO NETO, 2010). Assim sendo, a educação constitui o pilar central das estratégias para promover e aprofundar os valores e comportamentos que o desenvolvimento sustentável demanda (UNESCO, 2005).

Enquanto ainda não existe um centro de visitantes para suprir as necessidades dos turistas, no PARNA Serra do Cipó, é necessário que se crie outras propostas de educação ambiental, como a implantação de trilhas interpretativas. Oliveira et $a l^{5}$. (1999 apud ROCHA et al., 2010) consideram que as trilhas interpretativas, que utilizam a própria paisagem como recursos didáticos, são alternativas para trabalhos educativos em campo a partir da análise de seus recursos e da interpretação de suas belezas. Se adequadamente planejadas, funcionam como grandes laboratórios para a reformulação da questão do individualismo nos processos coletivos, promovendo mudanças de valores, princípio básico da educação ambiental (MENDONÇA; NEIMAN, 2005).

\footnotetext{
${ }^{5}$ OLIVEIRA, R.T.; BLOOMFIELD, V.K.; MAGALHÃES, L.M.S. Trilha auto guiada: proposta de implantação e interpretação na Floresta Nacional Mário Xavier Sandra Regina da Costa. Floresta e Ambiente, v.6, n.1, p.138-
} 143, 1999. 
Rocha (1997) afirma que, além dos objetivos específicos de cada Unidade, os programas de educação e interpretação ambiental devem ter como objetivo geral quatro pontos principais: 1) criar ou fortalecer apoio público; 2) criar ou melhorar canais de comunicação entre a UC e a população; 3) desenvolver a consciência conservacionista e promover o reconhecimento local quanto à importância das UCs; e 4) servir como instrumento de envolvimento e participação pública.

Nesse sentido, Aguiar et al. (2010) acreditam ainda que:

Quando bem elaboradas, as trilhas conseguem promover o contato mais estreito entre o ser humano e a natureza, possibilitando conhecimento das espécies animais e vegetais, da história local, da geologia, da pedologia, dos processos biológicos, das relações ecológicas, ao meio ambiente e sua proteção, constituindo instrumento pedagógico extremamente importante (AGUIAR et al., 2010, p.504).

Visto que o Parque Nacional da Serra do Cipó é uma unidade de conservação, em que há regras de comportamento, procurou-se avaliar a consciência e as atitudes ambientais dos visitantes, através de uma série de questões relacionadas ao Parque e ao meio ambiente.

A lei 9.985/00 que estabelece o Sistema Nacional de Unidades de Conservação no Brasil define, em seu artigo 11, os principais atributos de um Parque Nacional:

O Parque Nacional tem como objetivo básico a preservação de ecossistemas naturais de grande relevância ecológica e beleza cênica, possibilitando a realização de pesquisas científicas e o desenvolvimento de atividades de educação e interpretação ambiental, de recreação em contato com a natureza e de turismo ecológico (BRASIL, 2000).

Dessa forma, foi pedido aos visitantes que classificassem, por ordem de importância, as atribuições básicas de um Parque. Sendo "1" a atividade que eles julgassem ser a mais importante e "4" a de menor importância.

A proteção da flora e fauna aparece como a principal atividade, com $64 \%$ das indicações dos visitantes, fato que demonstra que as pessoas reconhecem o objetivo principal de Parque. A pesquisa científica foi o segundo item mais citado, em seguida, a educação ambiental e, por último, a visitação. 
A visitação foi o item avaliado pelos visitantes como de menor importância para um Parque. Entretanto, uso público é um essencial instrumento de aproximação do visitante às Unidades de Conservação, favorecendo assim, seu envolvimento com as questões ambientais.

Para tanto, há a necessidade de planejamento, de investimentos em infra-estruturas básicas, de apoio e turísticas, de capacitação de pessoas, de adequadas formas de controle e gestão, de participação e valorização da população local, e de benefícios econômicos que promovam emprego e renda as comunidades, bem como garantam a manutenção da biodiversidade por incremento da pesquisa científica, entre outros (MMA, 2007).

Assim sendo, Bueno (2010) acredita que cabe a cada unidade de conservação formular e inserir em seus respectivos planos de manejo, programas e subprogramas de uso público que visem à estruturação e à qualificação da visitação.

No entanto, quando não é devidamente planejada e monitorada, a visitação pode gerar impactos negativos como a degradação do meio ambiente e a descaracterização paisagística, podendo ainda acarretar riscos para os próprios visitantes, além de não satisfazer os objetivos da educação ambiental. Para Ruschmann (2002), o planejamento do ecoturismo é um instrumento poderoso para acelerar e maximizar os efeitos positivos da atividade, minimizar os efeitos negativos e fomentar o desenvolvimento sócio-econômico de uma comunidade.

O autor enfatiza que as comunidades receptoras devam ser conscientizadas da importância da atividade em si e da conservação da autenticidade dos recursos naturais, pois deles depende o futuro turístico da localidade e conseqüentemente, as suas oportunidades de emprego e de complementação do orçamento doméstico.

Para Irving e Azevedo (2002) quando se preza a conservação dos recursos naturais e culturais e o bem-estar das populações envolvidas, deve-se estabelecer, também, um compromisso ético, no qual se pressupõe "uma filosofia de vida diferenciada, norteada pelo compromisso de justiça social, democratização de oportunidades e percepção de longo prazo numa visão coletiva, solidária, e não egocêntrica" (IRVING; AZEVADO, 2002, p.31).

Para tanto, o papel da educação ambiental é inquestionável. As autoras vêem como um grande desafio, a implantação de modelos de desenvolvimento regional integrado, nos quais o 
ecoturismo represente uma alternativa econômica, e a educação ambiental, um mecanismo eficaz de exercício de cidadania, a partir da consciência de valor do bem natural.

Foi também perguntado aos visitantes, a quem eles atribuem a responsabilidade de conservação do Parque. O resultado foi bem equitativo, tendo $32 \%$ dos entrevistados consideram a comunidade como a principal responsável pela conservação do Parque, seguida pelos visitantes, com 29\%, e pelos órgãos do governo, com $28 \%$. Os $11 \%$ restantes, que assinalaram a opção "outros", atribuíram a responsabilidade de conservação do Parque principalmente, as ONGs, as Universidades e a sociedade como um todo.

Uma vez que os visitantes conferiram a si próprios, parte da responsabilidade de conservação do Parque, foi questionado como os mesmos poderiam contribuir para tal. A maior parte das respostas foi referente à manutenção do ambiente físico do Parque, uma vez que a maioria dos visitantes cita o cuidado com o lixo como sua principal contribuição na conservação do Parque, como os dizeres a seguir:

- "Não jogando lixo e respeitando as regras do Parque"

- "Cuidando do meu lixo"

- "Não poluindo o Parque e preservando fauna e flora"

- "Recolhendo lixo"

- "Contribuindo com a limpeza e recolhimento do lixo e não tirar plantas"

Apesar da importância da preocupação com lixo, existem também outras atitudes que podem ajudar, e muito, na conservação de ambientes naturais como um todo. $\mathrm{O}$ respeito à natureza, a preocupação com a minimização dos impactos da visita, a educação ambiental e a prática do turismo sustentável foram outras maneiras, citadas pelos entrevistados, de ajudar na conservação desses ambientes:

- "Aproveitando a natureza de maneira respeitosa, não interferindo no ambiente"

- "Respeitando a natureza"

- "Praticando o turismo responsável"

- "Praticando atividades com menor impacto possível, com o grupo reduzido de pessoas"

- "Ajudando a preservar e a fiscalizar"

- "Fazendo educação ambiental" 
Além disso, divulgar práticas sustentáveis e atitudes conservacionistas é uma excelente maneira de incentivar outras pessoas a assumirem, também, sua responsabilidade na conservação das áreas naturais protegidas.

- "Divulgando boas práticas em atividades no meio natural"

- "Participando e incentivando as pessoas a participarem de atividades ambientais/ecoturismo"

- "Compartilhando conhecimento adquirido com outras pessoas"

Baseado em tais falas, questionou-se aos visitantes, se eles estariam dispostos a seguir regras de conservação em favor da natureza, e $100 \%$ de respostas afirmativas foram obtidas. No entanto, se essas regras implicassem na restrição de sua liberdade na natureza, apenas 52\% dos entrevistados concordariam. Os outros $45 \%$ não estariam dispostos a seguir tais regras a favor da natureza, caso isso restringisse sua liberdade, e apenas 3\% dos entrevistados não se manifestaram.

Nesse sentido, Wearing e Neil (2001) acreditam que:

A única maneira de preservar e alimentar outras liberdades mais importantes (como a das comunidades que acolhem) é renunciar à liberdade de visitar ou limitar o número de visitantes. Nestes termos, a liberdade é o reconhecimento da necessidade, a necessidade de renunciar à liberdade (humana) pessoal ou individual colocando restrições ao número de visitantes e limitando o alcance das experiências de viagem dos ditos visitantes (WEARING; NEIL, 2001, p.47).

Foi ainda perguntado aos visitantes se, baseados em suas atitudes durante a visita, se eles se consideravam ecoturistas. $52 \%$ dos entrevistados afirmaram que sim, e assim o justificaram conforme transcrito abaixo:

- "Faço visitas mensais a diversos lugares"

- "Tenho prazer em interagir com a natureza"

- "Gosto e cuido da natureza e tudo relativo a ela"

- "Faço turismo consciente"

- "Porque gosto de passar meu tempo livre na natureza e dou importância pra ela"

- "Acho de extrema importância a preservação e conservação e visitação periódica de parques" 
- "Gosto de caminhar nas matas, gosto da natureza, admiro e preservo"

- "Porque passeei sem danificar o meio ambiente"

Embora a maioria dos visitantes tenha se denominado ecoturista, nota-se, pelas justificativas dadas pelos mesmos, que essa afirmação, na maioria dos casos, não é pertinente. Uma vez que seus valores, principalmente, sobre as questões ambientais se mostram distantes dos conceitos de ecoturismo e educação ambiental, tratados anteriormente

Para Ceballos Lascuráin 6 (1998 apud NIEFER et al., 2000), o termo "ecoturismo" somente deve ser usado se: a atividade turística acontece num ambiente natural, encoraja a conservação e ajuda a sociedade a alcançar um desenvolvimento sustentável. Entretanto, o que geralmente os visitantes fazem é o que poderia ser chamado de passeio na natureza, turismo ecológico ou qualquer outra atividade, e não ecoturismo propriamente dito, uma vez que são negligenciados os princípios fundamentais desta atividade (CAMPOS, 2010).

Outra confusão freqüente é em relação ao ecoturismo e o turismo de aventura. Muitos dos entrevistados utilizaram os dois termos como sinônimos, reforçando o distanciamento existente entre os conceitos acadêmicos e como os visitantes se auto-definem.

Embora ambos aconteçam em ambientes naturais e se preocupem com a minimização dos impactos, o turismo de aventura e o ecoturismo divergem em alguns pontos. Hintze (2009) considera que exista uma linha tênue e difícil de ser apreendida, o que costuma gerar confusão entre os dois conceitos. No entanto, o autor aponta uma diferença básica entre eles: a educação ambiental; que participa conceitualmente do ecoturismo, mas não do turismo de aventura. No entanto, é importante ressaltar que a interpretação ambiental é um instrumento que tem a possibilidade de ser trabalhada em ambos os casos.

Para Pires (2002), uma diferenciação fundamental entre eles, é que o ecoturismo deve contemplar a educação ambiental, a integração cultural dos participantes com os habitantes locais e a atenção para com os impactos negativos das atividades no ambiente natural onde se desenvolvem.

6 CEBALLOS-LASCURÁIN, H. Introduction In: Ecoturism: a guide for planners and managers, vol. 2. The Ecotourism Society, North Benoington, Vermont, 1998. 
No entanto, observaram-se também, exemplos de visitantes que parecem estar mais sintonizados com a dimensão global do ecoturismo. Uma vez que incorporam em suas respostas, além dos aspectos ambientais, também os sociais, econômicos e culturais, se preocupando, assim, com a sustentabilidade da atividade:

- "Pois pratico o turismo responsável, de forma integrada à natureza, valorizando o local e sua cultura, de forma sustentável"

- "Principalmente porque me preocupo com o impacto da minha visita aos locais e evito deixar resíduos, alimentar animais, recolher plantas, andar fora da trilha, infringir as regras do parque, etc. Além disso, me preocupo também com os impactos à comunidade do entorno. Não acho que ecoturista seja apenas aquele turista que passeia em meio à natureza".

Nesse sentido, Gontijo (2003) diz que ecoturismo, para os visitantes da Serra do Cipó, parece significar desde um banho de cachoeira na superlotada Cachoeira Grande, até uma caminhada de longa distância em áreas pouco freqüentadas e durante a qual são experimentadas relações profundas de interação com a paisagem e seus habitantes.

O autor ainda descreve que grande parte dos visitantes acha que, por procurarem um contato mais próximo com a natureza, estão sendo ecológicos, o suficiente, para rotularem-se como ecoturistas. Apesar de muitos estarem até bem intencionados, não percebem o alcance da dimensão que a presença deles, em tais destinos, acarreta para o meio ambiente e/ou para as comunidades locais.

Em contrapartida, $42 \%$ dos entrevistados não se consideram ecoturistas e $6 \%$ não responderam. Entre as justificativas do porquê de não se considerarem ecoturistas, destacam-se:

- "Porque eu não faço muitas viagens à natureza"

- "Não tenho disponibilidade"

- "Sou só turista"

- "Não costumo fazer esse tipo de programa com freqüência"

- "Não tenho muitas oportunidades com freqüência"

- "Porque julgo muito poucas as viagens e atividades que faço"

- "Estou querendo começar a ser, mas ainda não me considero"

Nota-se que a maioria das respostas diz respeito à falta de tempo e/ou oportunidade para realizar o ecoturismo. Simiquelli (2008) obteve resultado semelhante no Parque Estadual do 
Ibitipoca em que $66 \%$ dos entrevistados não se consideraram ecoturistas devido à baixa freqüência de visitação a áreas naturais.

Entretanto, não é necessária uma alta freqüência de viagens para que uma pessoa seja considerada um ecoturista. São as atitudes destas pessoas em suas atividades junto à natureza que a qualificam, ou não, como ecoturistas.

Para Niefer et al. (2000), a vontade do consumidor, no caso o ecoturista, de aprender sobre o destino visitado, principalmente sobre os aspectos ambientais, culturais, históricos e seus problemas relacionados é que o diferencia de um turista comum. Assim, "ecoturística deve ser a atitude da pessoa que vai empreender a viagem, qualquer que seja o destino" (GONTIJO, 2003, p.183).

Neste contexto, os exemplos anteriores reforçam a afirmação de Irving e Azevedo (2002) de que o ecoturismo na proximidade de UC's, embora se baseie em atrativos naturais de grande relevância e pregue a distribuição de benefícios à população local, é ainda pouco praticado no Brasil em sua concepção mais global.

De uma maneira geral, a maioria (94\%) dos visitantes da Serra do Cipó se mostrou bastante satisfeita com a visita. Enquanto 6\% disseram estar mais ou menos satisfeitos e nenhum dos entrevistados se mostrou insatisfeito. E ainda, todos os visitantes entrevistados manifestaram intenção de retornar à Serra do Cipó.

Petrocchi (1998) alerta que se a avaliação que o turista faz da visita, se for positiva, por certo, ele influenciará outros que poderão ir àquela cidade. Mas, se a avaliação for negativa, muitos visitantes poderão escolher outros destinos, pois a oferta é muito grande no mercado do turismo. A avaliação negativa é, então, em longo prazo, uma real ameaça à sobrevivência do sistema turístico. Portanto, é importante a manutenção do alto o nível de satisfação do turista, assegurando uma experiência significativa que possibilite maior conscientização ambiental e promova práticas sustentáveis entre os mesmos (CAMPOS, 2010).

Por fim, foi destinado um espaço no final do questionário para que os entrevistados pudessem fazer comentário e/ou sugestão. No entanto, apenas $21 \%$ o fizeram. Com exceção de alguns poucos elogios referentes à beleza natural do Parque e algumas manifestações de satisfação 
com a visita. A maioria dos comentários foram críticas à infra-estrutura do Parque bem como sugestões para melhoria da qualidade da visita. Destacam-se:

- "Implantar lixeiras ao longo das trilhas, implantar lanchonete, hoje o bebedouro não estava funcionando direito"

- "Loja de conveniência"

- "Oferecer ao público externo o conforto mínimo para maior satisfação"

- "Melhorar a estrutura para recepção e apoio ao turista"

- "Posto de gasolina, caixa eletrônico"

- "Permissão para percorrer a trilha de carro devido às enormes distâncias para as cachoeiras"

- "Só existe um chuveiro quente no vestiário"

Alguns comentários demonstram a falta de afinidade e mesmo o despreparo de alguns entrevistados em suas relações com a natureza. Isso reflete na vontade dos visitantes de inserir alguns elementos da urbanidade no ambiente natural, sem considerar os impactos negativos que isso possa causar. $\mathrm{O}$ que enfatiza o fato de alguns dos visitantes não se sentirem à vontade nesse tipo de ambiente, como demonstrado nos comentários.

Para Gontijo (2003, p.183), “o problema é que não queremos abrir mão de nossos confortos, não queremos nos afastar dos mitos da sociedade moderna - do mito do possibilismo tecnológico, do mito do possibilismo monetário, do mito recente da globalização”. Nesse sentido, Neiman (2007) acredita que se não houver processos de percepção e interpretação ambiental individuais, capazes de modificar essa realidade, a viagem resume-se apenas a uma bela coleção de fotos.

De acordo com Krippendorf (2003), uma nova compreensão das viagens e um novo comportamento durante as mesmas poderiam contribuir para desenvolver um senso de humanidade e de equidade. Em quase todos os destinos, tem-se constatado a falta de "cultura turística" das pessoas que viajam, o que faz com que se comportem de forma alienada em relação ao meio que visitam. "Aprendemos a ler, a calcular, a dançar, a comprar, a dirigir, etc. Mas teríamos aprendido a viajar?” (KRIPPENDORF, 2003, p.180).

As sugestões deixadas pelos entrevistados indicam que há uma real necessidade de ações educativas para formar e informar os visitantes. Barros (2003) acredita que alguns 
comportamentos inadequados possam ser modificados através de programas voltados para a educação dos visitantes. No entanto, estes programas precisam ir além de simplesmente ensinar o que os visitantes devem fazer, eles devem objetivar mudar o modo como as pessoas pensam e avaliam o seu comportamento. "Mais do que conscientizar (campo da 'razão') é preciso sensibilizar (universo restrito das 'emoções')” (NEIMAN, 2007, p. 132).

Mas, para Sandeville Júnior e Suguimoto (2010), o grande desafio consiste em conseguir transformar essa sensibilização em educação e, consequentemente, em ações afetivas e efetivas. "Distribuir panfletos ou qualquer outro material informativo aos turistas não é Educação Ambiental, é apenas informação, por vezes discutível. Contratar um guia local com falas decoradas também não é Educação Ambiental, é superficialidade" (SANDEVILLE JÚNIOR; SUGUIMOTO, 2010, p.56).

Torna-se evidente então, que esse modelo de educação ambiental não tem surtido o efeito necessário. Bueno (2010) afirma que grande parte do que se realiza enquanto educação ambiental, em Unidades de Conservação, não consegue atingir o ponto de sensibilização, uma vez que as atividades são desenvolvidas do ponto de vista meramente contemplativo ou puramente informativo. $\mathrm{O}$ autor também enfatiza que são necessárias formas específicas de educação ambiental, capazes de promover a sensibilização e a reflexão nos visitantes, como etapas de um processo de transformação crítica.

Parece ser consenso entre os especialistas, que o contato com a natureza é um grande estímulo à sensibilização sobre o ambiente e à sua conservação. Nesse sentido, Neiman (2007) acrescenta que, se esse contato com a natureza for proporcionado de maneira adequada, estimulando todos os sentidos, como por exemplo, sentir o cheiro da mata, olhar os animais, ouvir os barulhos, há uma melhora de sentimentos positivos em relação ao que deve ser conservado. Afinal "não é apenas através do sentimento ético de obrigação que se pode trabalhar o gosto pela natureza e pela conservação" (NEIMAN, 2007, p.18).

Dessa forma, a educação ambiental através do ecoturismo não pode ser uma atividade isolada de todas as outras, ela deve ser complemento, constituir um meio de conscientização ambiental, deve ser uma possibilidade e um exercício de interpretação e valorização dos lugares (SANDEVILLE JÚNIOR; SUGUIMOTO, 2010). 
Portanto, a utilização de áreas naturais deve estar inserida em uma preocupação no incremento da conscientização ambiental, de forma a proporcionar ao visitante o envolvimento com as questões ecológicas, sociais, econômicas e culturais do destino. Eis o papel da educação ambiental no ecoturismo, ou ainda, do ecoturismo na educação ambiental.

\section{Considerações Finais}

Destaca-se neste estudo, a importância de se conhecer o perfil e a percepção dos turistas que visitam unidades de conservação de forma a propiciar uma maior integração destes aspectos no planejamento do uso público e, conseqüentemente, garantir uma experiência rica e agradável aos visitantes sem causar impactos significativos aos recursos naturais e culturais da área. Portanto, é necessário o desenvolvimento de um programa de monitoramento constante deste perfil bem como da opinião do visitante.

A Serra do Cipó possui vários destinos, com diferentes graus de acessibilidade, sugerindo a continuidade de um processo de assédio turístico cada vez maior. Pode-se dizer que na região ocorre tanto a prática do ecoturismo, como do turismo de massa, sem nenhuma busca por conhecimento da cultura local e com práticas de educação ambiental.

A linha que separa o ecoturismo do turismo de massa em ambientes naturais é frágil e sutil, e pode ser ultrapassada sem que os responsáveis pelo manejo se dêem conta disso. Dessa maneira, o turismo na região necessita de mais estudos que auxiliem no planejamento e gerenciamento do espaço turístico, do uso público e das necessidades dos visitantes e da comunidade local, evitando assim a deterioração do destino.

A fim de minimizar os impactos causados pelo turismo, tanto para a comunidade quanto para o Parque, e garantir um melhor aproveitamento da visita pelos turistas, recomenda-se a adoção das práticas de educação ambiental. Uma vez que esta constitui uma das principais ferramentas existentes para a sensibilização e capacitação dos visitantes a respeito daquele ambiente natural em suas potencialidades e fragilidades. Por conseguinte, destaca-se a importância da utilização dos princípios do ecoturismo na região receptora da atividade. Dessa forma, talvez seja possível que o turismo venha a ser verdadeiramente econômica, social, cultural e ecologicamente sustentável, além de fonte de conservação ambiental. 


\section{Referências}

AGUIAR, P.W.; PADUA, S.M.; GOMES, M.A.O.; UEZU, A. Subsídios para o planejamento de trilha no Parque Estadual da Serra Furada (SC). Revista Brasileira de Ecoturismo, São Paulo, v.3, n.3. p. 498-527, 2010. Disponível em:

$<$ http://www.sbecotur.org.br/rbecotur/artigos/artigo40.pdf $>$. Acesso em: 30 set. 2010.

BARROS, M.I.A.; DINES, M. Mínimo impacto em áreas naturais: uma mudança de atitude. In: SERRANO, C. (Org.). A educação pelas pedras: ecoturismo e educação ambiental. São Paulo: Chronos, 2000. p.47-84.

BARROS. M. I. A. de. Caracterização da visitação, dos visitantes e avaliação dos impactos ecológicos e recreativos do planalto do Parque Nacional do Itatiaia. 2003. 121 f. Dissertação (Mestrado em Recursos Florestais). Universidade de São Paulo, Piracicaba, 2003.

BENI, M. C. Análise estrutural do turismo. 12 ed. São Paulo: SENAC, 2007. 556 p.

BRASIL. Diretrizes para uma Política Nacional de Ecoturismo. Brasília: EMBRATUR, $1994.48 \mathrm{p}$.

. Lei n. 9.985 de 18 de julho de 2000. Regulamenta o art. 225, § $1^{\circ}$, incisos I, II, III e VII da Constituição Federal, institui o Sistema Nacional de Unidades de Conservação da Natureza e dá outras providências. Diário Oficial [da] República Federativa do Brasil, Brasília, DF, 18 jul. 2000. Disponível em $<$ http://www.planalto.gov.br/ccivil_03/Leis/L9985.htm>. Acesso em: 25 set. 2010.

BUENO, F. P. Vivências com a natureza: uma proposta de Educação Ambiental para o uso público em Unidades de Conservação. Revista Brasileira de Ecoturismo. v.3, n.1, p.61-78. 2010. Disponível em: $<$ http://www.sbecotur.org.br/rbecotur/artigos/artigo19.pdf $>$. Acesso em: 15 out. 2010.

CAMPOS, R. F. Perfil, Percepção Ambiental e Qualidade da Experiência dos Visitantes da Serra do Cipó/MG. 2010. 108 f. Monografia (Especialização em Ecoturismo) - Universidade Federal de Lavras, Lavras, 2010.

DIAS, G.F. Educação Ambiental: princípios e práticas. São Paulo: Gaia, 2003. 551p.

DUTRA, V. C.; SENNA, M. L. G. S. de; FERREIRA, M. N. e; ADORNO, L. F. M. Caracterização do perfil e da qualidade da experiência dos visitantes no Parque Estadual do Jalapão, Tocantins. Caderno Virtual de Turismo. v.8, n.1, p. 104-117. 2008. Disponível em $<$ http://www.ivt.coppe.ufrj.br/caderno/ojs/viewissue.php?id=27>. Acesso em: 16 out. 2010.

FARIA, D. S. de; CARNEIRO, K. S. Sustentabilidade ecológica no turismo. Brasília: UnB, 2001. 95p.

FORTUNATO, I.; FORTUNATO NETO, J. A política nacional de educação ambiental e a sustentabilidade ambiental. Educação ambiental em ação. n 32. jun/ago 2010. Disponível em: $<$ www.revistaea.org/artigo.php?idartigo $=861 \&$ class $=02>$. Acesso em: 15 set. 2010 .

GONTIJO, B.M. Ilusão do ecoturismo na Serra do Cipó/MG: caso de Lapinha. 2003. 192 f. Tese (Doutorado em Desenvolvimento Sustentável, área de concentração em Política e Gestão Ambiental) - Centro de Desenvolvimento Sustentável da Universidade de Brasília, Brasília, 2003. 
HINTZE, H. C. Ecoturismo na cultura de consumo: possibilidade de educação ambiental ou espetáculo? Revista Brasileira de Ecoturismo, São Paulo, v.2, n.1, p.57-100, 2009. Disponível em: <http://www.physis.org.br/rbecotur/>. Acesso em: 19 set. 2010.

IBAMA - Instituto Brasileiro do Meio Ambiente e dos Recursos Naturais Renováveis. Parque Nacional da Serra do Cipó. 2004. Disponível em:

$<$ http://www.ibama.gov.br/siucweb/listaUcCategoria.php?abrev=PARNA $>$. Acesso em: 21 set. 2010 .

IRVING, M. de A.; AZEVEDO, J. Turismo: o desafio da sustentabilidade. São Paulo: Futura, 2002. 219 p.

KATAOKA, S. Y. Indicadores da qualidade da experiência do visitante no Parque Estadual da Ilha Anchieta. 2004.113 f. Dissertação (Mestrado em Recursos Florestais, com opção em Conservação de Ecossistemas Florestais) - Universidade de São Paulo, Piracicaba, 2004.

KINKER, S. Ecoturismo e Conservação da Natureza em Parques Nacionais. Campinas, SP: Papirus, 2002. 224 p.

KRIPPENDORF, J. Sociologia do turismo: para uma nova compreensão do lazer e das viagens. 3 ed. São Paulo: Aleph, 2003. 184 p.

LADEIRA, A. S.; RIBEIRO, G. A.; DIAS, H. C. T.; SCHAEFER, C. E. G. R. Schaefer; FERNANDES FILHO, E.; OLIVEIRA FILHO, A.T. O perfil dos visitantes do Parque Estadual do Ibitipoca (PEIb), Lima Duarte, MG. Revista Árvore, Viçosa-MG, v.31, n.6, p.1091-1098, 2007. Disponível em:

$<$ http://www.scielo.br/scielo.php?script=sci_arttext\&pid=S010067622007000600014\&lng=pt $\& n r m=i s o \& t \operatorname{lng}=\mathrm{pt}>$. Acesso em: 16 set. $20 \overline{10}$.

MARCATTO, C. Educação Ambiental: conceitos e princípios. Belo Horizonte: FEAM, 2002. $64 \mathrm{p}$.

MARCELLINO, N.C. Lazer e educação. 12 ed. Campinas: Papirus. 2007. 164 p.

MATTAR, F.N. Pesquisa de Marketing: metodologia, planejamento, execução, análise. 4 ed. São Paulo: Atlas, 1997. 336 p.

MARUJO, N.N.V. A Internet como Novo Meio de Comunicação para os Destinos Turísticos: o caso da Ilha da Madeira. Turismo em Análise, v.19, n.1, mai. 2008. p. 25-42. Disponível em: $<$ http://www.turismoemanalise.org.br/index.php/turismoemanalise/article/viewFile/7/7>. Acesso em 30 set. 2010.

MELO, R. S.; ANDRADE JÚNIOR, J. A. de; LINS, R.P.; MENEZES, D. A. de. Conduta consciente e técnicas de mínimo impacto no Parque Estadual Pedra da Boca (PB). OLAMCiência \& Tecnologia. v.8, n.1, p. 316-334. jan/jun. 2008. Disponível em:

$<$ http://cecemca.rc.unesp.br/ojs/index.php/olam/issue/view/719/showToc $>$ Acesso em: 2 set. 2010 .

MENDONÇA, R.; NEIMAN, Z. Ecoturismo no Brasil. Barueri, SP: Manole, 2005, p 17- 39. 
MMA - MINISTÉRIO DO MEIO AMBIENTE. Guia para montagem de centro de visitantes em Unidades de Conservação. Brasília: Ministério do Meio Ambiente, Instituto Brasileiro de Meio Ambiente e dos Recursos Naturais Renováveis. 1998. 90 p.

Diretrizes para Visitação em Unidades de Conservação. Brasília: Ministério do Meio Ambiente, Secretaria de Biodiversidade e Florestas, Diretoria de Áreas Protegidas. 2006. 61p.

. Informe Nacional sobre as Áreas Protegidas no Brasil. Brasília: Ministério do Meio Ambiente. Instituto Chico Mendes de Conservação da Biodiversidade. 2007.

MOREIRA, L.A.L. A (in)sustentabilidade do discurso da educação para o desenvolvimento sustentável do Banco Mundial. ETD - Educação Temática Digital, Campinas, v.9, n.2, p.2030. jun. 2008.

NEIMAN, Z. A Educação Ambiental através do contato dirigido com a natureza. 2007. $234 \mathrm{f}$. Tese (Doutorado em Psicologia) - Universidade de São Paulo, 2007.

NIEFER, I.A. Análise do perfil dos visitantes das ilhas de Superagüi e do Mel: marketing como instrumento para um turismo sustentável. 2002. 237f. Tese (Doutorado em Engenharia Florestal) - Universidade Federal do Paraná, Curitiba, 2002.

NIEFER, I. A.; SILVA, J. C. G. L. da; AMEND. M. Ecoturistas ou não? Análise preliminar dos visitantes do Parque Nacional de Superagui. Revista Turismo - Visão e Ação, v.2, n.6, p. 49-68. 2000. Disponível em:

$<$ https://www6.univali.br/seer/index.php/rtva/article/view/1320/0\%3E.>. Acesso em: 30 out. 2010 .

PETROCCHI, M. Turismo: planejamento e gestão. 3ed. São Paulo: Futura, 1998. 381p.

PIRES, P. dos S. Dimensões do Ecoturismo. São Paulo: SENAC, 2002. 269 p.

PROJETO DOCES MATAS - Grupo Temático de Interpretação Ambiental.

Manual de Introdução à Interpretação Ambiental. Belo Horizonte, 2002. 108 p.

ROCHA, F.; BARBOSA, F.P.; ABESSA, D.M.S. Trilha ecológica como instrumento de Educação Ambiental: estudo de caso e proposta de adequação no Parque Estadual XixováJapuí (SP). Revista Brasileira de Ecoturismo, São Paulo, v.3, n.3, p. 478-497. set. 2010. Disponível em: $<$ http://www.sbecotur.org.br/rbecotur/artigos/artigo39.pdf $>$. Acesso em: 15 set. 2010.

ROCHA, L.M. Unidades de Conservação e Organizações Não-governamentais em Parceria: programas de educação ambiental. In: PADUA, S.M.; TABANEZ, M.F. (org.) Educação Ambiental: caminhos trilhados no Brasil. Brasília: IPE, 1997. p. 237-245.

RUSCHMANN, D. van de M. Turismo no Brasil: análise e tendências. Barueri, SP: Manole, 2002. $165 \mathrm{p}$.

SANDEVILLE JÚNIOR, E.; SUGUIMOTO, F.T. Ecoturismo e (Des)Educação Ambiental. Revista Brasileira de Ecoturismo, São Paulo, v.3, n.1, p.47-60. jan. 2010. Disponível em: $<$ http://www.sbecotur.org.br/rbecotur/artigos/artigo18.pdf>. Acesso em: 30 set. 2010. 
SATO, C. S. Parque Nacional da Serra do Cipó, $M G$ : percepção ambiental e estabelecimento de áreas para educação. 2007. 182f. Dissertação (Mestrado em Ciências, área de Botânica) Universidade de São Paulo, São Paulo, 2007.

SIMIQUELLI, R.F. Perspectivas para a conservação do Parque Estadual do Ibitipoca - MG: participação social, avaliação, manejo e percepção ambiental. 2008. 172 f. Dissertação (Mestrado em Ecologia) - Universidade Federal de Juiz de Fora. Juiz de Fora. 2008.

VASCONCELOS, J. M. O. Interpretação ambiental. In: MITRUAD, S. (Org). Manual de ecoturismo de base comunitária: ferramentas para um planejamento responsável. Brasília: WWF Brasil, 2003. p 261 - 293.

VASCONCELLOS, J. M. de O. Educação e Interpretação Ambiental em Unidades de Conservação. Cadernos de Conservação, ano 3, n 4. Curitiba: O Boticário. 2006. 86p.

UNESCO. Década da Educação das Nações Unidas para um Desenvolvimento Sustentável,

2005-2014: documento final do esquema internacional de implementação. Brasília:

UNESCO, 2005.120p. Disponível em:

$<$ http://unesdoc.unesco.org/images/0013/001399/139937por.pdf>. Acesso em 30 set. 2010.

WEARING, S.; NEIL, J. Ecoturismo: impactos, potencialidades e possibilidades. Barueri, SP: Manole, 2001. 256p.

Recebido em: 09/12/2010 (1 ${ }^{\text {a }}$ versão) $24 / 04 / 2011$ ( $2^{\text {a }}$ versão)

Aprovado em: 11/07/2011 


\section{Anexo}

Bom dia/Boa tarde, esta é uma pesquisa que está sendo realizada para o curso de Mestrado em Meio ambiente e Turismo do Centro Universitário UNA. O objetivo é saber quem são as pessoas que visitam o Parque Nacional da Serra do Cipó e qual sua percepção sobre o destino. Os dados levantados serão tratados confidencialmente. Obrigada por sua participação.

1- Procedência: cidade: estado:

2- Sexo

( ) masculino

( ) feminino

3- Idade
( ) de 15 a 18 anos
( ) 19 a 24 anos
( ) 25 a 34 anos
( ) 35 a 45 anos
( ) 46 a 59 anos
( ) mais de 60 anos

\section{4- Escolaridade}
( ) Ensino Fundamental
( ) Ensino Médio
( ) Ensino Superior
( ) Especialização
( ) Mestrado
( ) Doutorado

\section{5- Renda mensal individual:}
( ) sem renda
( ) até $\mathrm{R} \$ 1000,00$
( ) de 1.000 a 2.000
( ) de 2.000 a 4.000
( ) de 4.000 a 6.000
( ) de 6.000 a 10.000
( ) mais de 10.000

6- Qual o PRINCIPAL motivo de sua visita?
( ) atividades culturais
( ) lazer e diversão
( ) praticar esportes, qual/quais?
( ) atividades na natureza
( ) descansar
( ) outro

7- Com que frequência você visita a Serra do Cipó?
( ) $1^{\mathrm{a}}$ vez
( ) até $3 \mathrm{x} / \mathrm{ano}$
( ) mais de 3x/ano. Quantas?

8- Qual o seu interesse em praticar as seguintes atividades abaixo, em sua visita?
(0) não tenho interesse
(1) pouco
(2) médio
(3) muito

( ) caminhada curta (menos de $2 \mathrm{hs}$ )

( ) fotografia

( ) caminhada longa (mais de $2 \mathrm{hs}$ )

( ) observação da fauna/flora

( ) atividades com a população local

( ) banho de rio/cachoeiras

( ) visita a locais históricos

( ) participação em projetos de pesquisa

( ) vida noturna (festas, bares, etc)

9- Quantas viagens à natureza você fez este ano?
10- Gostaria de obter mais informações sobre o Parque?
( ) $\operatorname{sim}$
( ) não

11- Como gostaria de obter essas informações?
( ) Mapas/folhetos
( ) guias/condutor
( ) palestras/funcionários do Parque
( ) Internet
( ) $\mathrm{TV} /$ radio/jornal
( ) centro de visitantes 
12- Você considera importante que o Parque tenha um centro de visitantes?
( ) muito importante
( ) pouco importante
( ) não vê importância

13- O que você gostaria de ver no centro de visitantes? (marque no máximo 3 opções)

( ) informações sobre meio ambiente e biodiversidade

( ) informações específicas do Parque

( ) informações gerais sobre a região da Serra do Cipó

( ) história da Serra do Cipó e do Parque

( ) atividades de educação ambiental

( ) outros

14- Enumere as atividades abaixo segundo a importância que possuem um Parque:

(de 1 - mais importante até 4 - menos importante)
( ) visitação
( ) fiscalização
( ) proteção da fauna e flora
( ) educação ambiental

15- A quem você atribui a responsabilidade de conservação do Parque?
( ) órgãos do governo
( ) comunidade
( ) turistas
( ) outros

16- Como você acha que também possa colaborar para a conservação do ambiente do Parque?

17- Você está disposto a seguir regras a favor da conservação da natureza?
( ) $\operatorname{sim}$
( ) não

Mesmo que isto reduza a sua liberdade?

( ) $\operatorname{sim}$

( ) não

( ) não sei

18- Você se considera um(a) ecoturista? ( ) sim （ ） não

Porquê?

19- Numa avaliação geral, você está satisfeito com a sua estadia aqui?
( ) $\operatorname{sim}$
( ) não
( ) mais ou menos

20- Tem intenção de retornar à Serra do Cipó em outra oportunidade?
( ) $\operatorname{sim}$
( ) não
( ) talvez

21- Para finalizar, você gostaria de fazer mais algum comentário ou deixar alguma sugestão? 